\title{
HOW VIDEO DUBBING CAN IMPROVE STUDENTS' SPEAKING PRONUNCIATION
}

\author{
Firdaus Ditya Pamungkas \\ Sebelas Maret University \\ affditya@gmail.com
}

\begin{abstract}
This research aims to find out the impact of video dubbing on improving students' speaking pronunciation. This research was classroom action research and was applied for the tenth grade and eleventh grade of Vocational High School in Madiun city, province of East Java, Indonesia. The subject of the research consisted of 20 students, 14 female students and 6 male students. In collecting the data, researcher used observation to observe the implementation of video dubbing during teaching learning process and test to find the improvement of students' speaking pronunciation during the implementation of video dubbing. The research was conducted in two cycles, where each cycle consisted of 4 meetings. The research findings showed that the implementation of video dubbing could improve students' speaking pronunciation. It can be concluded that the implementation of video dubbing in learning process has beneficial effect on students' speaking skill, especially in pronunciation.
\end{abstract}

Keywords: video dubbing, teaching speaking, pronunciation.

\section{A. INTRODUCTION}

I

$\mathrm{n}$ this modern era, English as international language has important role in education (Mahu, 2012, p.374). English helps teachers and students to interact with foreign people to get various sources of knowledge. The main objective of English learning is to enable students to do English communication skill both in written and spoken form. The purpose of English learning is to develop students' language skills; listening, speaking, reading and writing. However, those skills are not easy to be mastered due to the various aspects of each skill that need to be learned.

Among four language skills mentioned above, speaking is considered as the most important skill because individual who learns a language is referred to as the speaker of that language (Ur, 1996 in Leong \& Ahmadi, 2017, p. 34). According to Nunan (2003, p. 48), speaking is a productive aural/oral skill and it consists of producing systematic verbal utterances to convey meaning. Meanwhile, Hughes (2003, p. 130) explains that there are five aspects of speaking, they are pronunciation, grammar, vocabulary, fluency, and comprehension. 


\section{Firdaus, How Video Dubbing can...}

\section{The Problem}

Researcher did a preliminary research at English club of Vocational High School in Madiun city, province of East Java, Indonesia, which is consisted of 20 students. There were some problems in English learning. First, speaking abilities of students were quite low. They still made some mistakes in their speaking such as incorrect pronunciation, many pauses in their direct speaking, and confused to use the correct tenses. Based on the result of test, the score of pronunciation was the lowest among five aspects of speaking. Therefore, researcher wanted to improve students' pronunciation in this research.

Second, students lost their confidences to speak English. They were passive when teacher asked about the students' opinion. The less confidence of students would cause nervousness that affect the students' speaking pronunciation and fluency. This situation can be seen when they were afraid of making mistakes in English speaking, then they would rarely speak English in their daily activities.

Furthermore, problems could be from teachers where teachers could not create the effective learning situation for students. Teacher seldom used media when she taught like video, pictures, or audio. Besides, teacher seldom taught speaking in learning process in the class. Teacher only wrote their explanation on whiteboard, and asked students to do the exercises.

\section{The Solution}

Dealing with these problems, teacher needs the best teaching strategy to improve students' speaking skill especially in pronunciation. The use of technology can be an effective way to be combined with English teaching and learning. Technology also can help students to improve their speaking pronunciation. Video dubbing is one of learning media that is suitable for speaking. Dubbing is the replacement of the original speech by a voice track which attempts to follow as closely as possible the timing, phrasing and lip-movements of the original dialogue (Luyken cited in Tanase and Cuza, 2014, p. 970). Dubbing can improve vocabulary acquisition, speaking fluency and pronunciation, fun activity fostering creativity and initiative (Danan, 2010: p.60). Therefore, researcher tried to use video dubbing as learning media to improve students' speaking pronunciation. 
Volume 5, Number 01, June 2019

\section{B. REVIEW OF LITERATURE}

\section{Speaking}

\section{Definition}

Speaking is major aspect of language learning. Speaking as one of language skills also has great role in communication. Therefore, speaking needs to be mastered by language learners to achieve fluent communication. Jones (1996, p. 12), as cited in Richards (2008, p. 19) states that in speaking, we tend to be getting something done, exploring ideas, working out some aspect of the world, or simply being together. According to Chaney (1998, p. 13), as cited in Kayi (2006), Speaking is the process of building and sharing meaning through the use of verbal and nonverbal symbols, in a variety of contexts. Meanwhile, Thornbury (2005, p. 20) explains that speaking is a real life activity that is carried out by speaker to express ideas to interact with listeners. The activities are unplanned and their continuity is based on situations. In addition, according to Nunan (2005, p. 46), speaking is a process of creating an utterance that is made to form words and phrases. It can be concluded that speaking is a process of building and sharing meaning to express speaker's idea to listener.

\section{Aspect of Speaking}

Brown (2004: p. 157) explained that there are five components of speaking. They are grammar, vocabulary, comprehension, fluency, and pronunciation. Meanwhile, Head and Burgess (2005, p. 106-108) stated that there are some sub-skills tend to cover the speaking test: fluency, grammar, vocabulary, and pronunciation. Syakur (1987, p. 5) explained that speaking is a complex skill and at least it is concerned with components of grammar, vocabulary, pronunciation, and fluency. According to Hughes (2003, p. 130), there are five categories of testing oral ability, they are pronunciation, grammar, vocabulary, fluency, and comprehension. Based on the theory from Brown and Hughes, the researcher concludes that aspects of speaking can be categorized into 5 aspects, they are grammar, pronunciation, vocabulary, fluency and comprehension.

\section{Pronunciation}

\section{Definition}

Pronunciation is a sub-skill of speaking and it can be categorized as important aspect of speaking. Kreidler (2004, p. 5) explained that pronunciation is the way sounds are articulated by the speaker and those sounds are organized into a system, the sound system of a specific language. Meanwhile, according to Fraser (2001, p. 6), pronunciation is aspect of speech which 


\section{Firdaus, How Video Dubbing can...}

makes for an easily intelligible flow of speech, including segmental articulation, rhythm, intonation and phrasing, and more peripherally even gesture, body language and eye contact. In addition, Cook (1996) as cited in Gilakjani (2016) defined pronunciation as the production of sounds that is learnt by repeating sounds and correcting them when produced inaccurately. In the beginning of learning pronunciation, learners start to make new habits and overcome the difficulties resulting from the first language. It can be concluded that pronunciation is the production of sounds by the speakers and those sounds are organized into a specific language.

\section{Aspect of Speaking}

According to Kenworthy (1987, p. 9), there are some various aspects of pronunciation, they are:

1. Sounds

There are two type of sounds, vowels and consonants. Vowels and consonants perform different functions in syllable. According to Yule (2010, p. 33), vowel sounds are produced with a relatively free flow of air. Meanwhile, consonants are speech sound produced by restricting the airflow in some way. There are two ways in describing consonants, they are place and articulation and manner of articulation.

2. Stress

According to Fraser (2001, p. 21), stress is one of the main tools used in English to convey word and sentence meanings. It is essential for speakers to control the stress system if they are to speak English intelligibly. Stress can be a major problem for learners. The problem is not that learners can't physically produce stressed and unstressed syllables but they make errors by not using stress appropriately for English.

3. Rhythm

Deterding (1998, p.104) explained that rhythm is relatively more important in some languages than others in helping listeners to interpret utterances. Stress and rhythm work together with intonation to convey meaning about the speaker's intent, the personal relationship between speaker and listener.

4. Intonation

Intonation is called the rise and fall of the voice or the time of speech. (Deterding, 1998, p. 111) It involves pitch and changes in pitch. 
Volume 5, Number 01, June 2019

\section{Scoring in pronunciation}

Hughes (2003, p. 130) explained that analytic scoring is one of scoring tests that can be used to test speaking performance. Hughes (2003, p. 100) argued that analytic score is method of scoring which requires a separate score for each of a number of aspects of a task. It is longer and it compels testers to take a variety of factors into account. The focus of this research is speaking pronunciation. Based on indicators of pronunciation that are taken before, there are sounds, stress, rhythm and intonations. Due to level of subjects of the research, the scoring rubric focused on parts of sounds; vowels, diphthongs and consonants.

Table 1. The modification of scoring rubric of pronunciation adapted from Pearson Test of English Academic's scoring rubric (2012)

\begin{tabular}{|c|c|c|c|}
\hline No & Criteria & Rating Score & Description \\
\hline \multirow{5}{*}{1.} & \multirow{5}{*}{ Vowels } & 50 & All vowels are produced clearly. The words are easily understandable \\
\hline & & 40 & $\begin{array}{l}\text { Vowels are produced clearly and unambiguously. A few minor } \\
\text { distortions do not affect intelligibility. At least } 3 / 4 \text { speech is } \\
\text { intelligible. }\end{array}$ \\
\hline & & 30 & $\begin{array}{l}\text { Most vowels are pronounced correctly. Some consistent errors might } \\
\text { make a few words unclear. at least } 1 / 2 \text { of speech is intelligible }\end{array}$ \\
\hline & & 20 & $\begin{array}{l}\text { Some vowels are pronounced correctly and the rest of them are } \\
\text { consistently mispronounced. At least } 1 / 4 \text { of speech is intelligible }\end{array}$ \\
\hline & & 10 & $\begin{array}{l}\text { Few vowels are pronounce correctly. The intelligibility is less than } \\
1 / 4 \text { of speech. Listeners have difficulty in understanding the speech. }\end{array}$ \\
\hline \multirow{5}{*}{2.} & \multirow{5}{*}{ Diphthongs } & 50 & $\begin{array}{l}\text { All diphthongs are produced clearly. The words are easily } \\
\text { understandable }\end{array}$ \\
\hline & & 40 & $\begin{array}{l}\text { Diphthongs are produced clearly and unambiguously. A few minor } \\
\text { distortions do not affect intelligibility. At least } 3 / 4 \text { speech is } \\
\text { intelligible. }\end{array}$ \\
\hline & & 30 & $\begin{array}{l}\text { Most diphthongs are pronounced correctly. Some consistent errors } \\
\text { might make a few words unclear. at least } 1 / 2 \text { of speech is intelligible }\end{array}$ \\
\hline & & 20 & $\begin{array}{l}\text { Some diphthongs are pronounced correctly and the rest of them are } \\
\text { consistently mispronounced. At least } 1 / 4 \text { of speech is intelligible }\end{array}$ \\
\hline & & 10 & $\begin{array}{l}\text { Few diphthongs are pronounce correctly. The intelligibility is less } \\
\text { than } 1 / 4 \text { of speech. Listeners have difficulty in understanding the } \\
\text { speech. }\end{array}$ \\
\hline \multirow{5}{*}{3.} & \multirow{5}{*}{ Consonants } & 50 & $\begin{array}{l}\text { All consonants are produced clearly. The words are easily } \\
\text { understandable }\end{array}$ \\
\hline & & 40 & $\begin{array}{l}\text { Consonants are produced clearly and unambiguously. A few minor } \\
\text { distortions do not affect intelligibility. At least } 3 / 4 \text { speech is } \\
\text { intelligible. }\end{array}$ \\
\hline & & 30 & $\begin{array}{l}\text { Most consonants are pronounced correctly. Some consistent errors } \\
\text { might make a few words unclear. at least } 1 / 2 \text { of speech is intelligible }\end{array}$ \\
\hline & & 20 & $\begin{array}{l}\text { Some consonants are pronounced correctly and the rest of them are } \\
\text { consistently mispronounced. At least } 1 / 4 \text { of speech is intelligible }\end{array}$ \\
\hline & & 10 & $\begin{array}{l}\text { Few consonants are pronounced correctly. The intelligibility is less } \\
\text { than } 1 / 4 \text { of speech. Listeners have difficulty in understanding the } \\
\text { speech. }\end{array}$ \\
\hline
\end{tabular}




\section{Firdaus, How Video Dubbing can...}

\section{Dubbing}

\section{Definition}

According to $\mathrm{Yu}$ (2013) as cited in Florente (2016, p. 20), the word dubbing has two meanings: in a broad sense it means to replace an existing soundtrack and in a narrow sense it means to do a type of lip-syncing to match the voices and lip movements of the existing source. Matamala (2010, p. 2) also stated dubbing is a complex process in which various agents take part. It means that, the translators and the dubbing actors are a series of professional work towards a common final goal. The goal is offering an audiovisual product in the target language that can be accepted by the audience as a credible illusion. Meanwhile, Requena (2015, p. 12) stated that dubbing is the re-voicing that could be done by muting the voice of the original actors. In addition, Borell (2000, p.4) stated that dubbing means the replacement of a soundtrack for a new one, with the different language than original. In other words, dubbing is the process re-voicing the original speech by muting the voice the original speech to reproduce the original message while at the same time ensuring that the target language sounds and the actors' lip movements are more or less synchronized.

Dubbing consists of a complex transfer process involving various steps, whose order may vary to a certain extent depending on local circumstance and preferences (Weisshaupt, 2017, p. 190). Martinez (2004) as cited in (Weisshaupt, 2017, p. 190) stated that dubbing translation is driven by following features: (1) a decision concerning which parts should be translated or left in their original language (e.g. songs, screen inserts); (2) the translation of film script by a translator, who uses the film itself and/or the written script, and rewriting of this initial translation by the translator or, more frequently, by a dialogue writer; (3) the synchronization of the translation of the translated dialogue to match the actors' lip movements and on screen actions, excluding written text; (4) the actual dubbing sessions in which actors implement the translated and adapted script. The purpose of dubbing is usually to make audio-visual material available for a broader group people. (Borrel, 2000, p. 4)

\section{Teaching Speaking using Dubbing}

In this modern era, there are many media that can be used by teacher to teach English. According to Javier et al (2013), as cited in Karimzadeh and Ghahroudi (2017, p. 4), dubbing as a pedagogical tool improves oral skills, translation and vocabulary acquisition. According to Burston (2005, p. 81), there are several ways to use video dubbing as learning media, they are: 
Volume 5, Number 01, June 2019

1. Learners can take a muted video clip and create from scratch their own storyline and accompanying script

2. Learners transcribe the dialog to ensure correctness and providing an explicit script that can be used for pronunciation practice. The script must not only be linguistically correct, but also contextually appropriate and synchronized with the video

3. Learners create a muted video using dubbing application or any video editor.

4. To help learners in adjusting the voice and video, learners should watch and hear the original video several times

5. The practice recording phase needs several trials to get the best result.

Due to teaching process using video dubbing above, the researcher creates his own teaching steps of video dubbing that focus on the improvement of speaking pronunciation, they are:

1. Teacher explains about English speaking in detail (include American English and British English)

2. Teacher explains about how to pronounce American English and British English. This activity can help to improve students' speaking pronunciation

3. Teacher gives practice to students related to American English and British English. This activity can help to improve students' speaking pronunciation

4. Teacher explains about the use of video dubbing in improving speaking pronunciation

5. Teacher provides a script for students for video dubbing practice

6. Teacher asks students to practice in adjusting their voice with a muted video for preparation of dubbing practice. This activity can help to improve, students' pronunciation and fluency.

7. Teacher asks students to create their own scripts for video dubbing practice. This activity can help to improve students' grammar, vocabulary, and comprehension.

\section{METHOD}

This research used Classroom Action Research. McNiff and Whitehead (2006, p. 7) stated that action research is a form of enquiry that enables practitioners everywhere to investigate and evaluate their work. Action research can be a powerful and liberating form of professional enquiry because it means that practitioners themselves investigate their own practice as they find ways of living more fully in the direction of their educational values. According to Kemmis and 
Mc'Taggart (2004, p. 18), in general, action research cycle contains planning of change, acting and observing the process and consequences of the change, reflecting on these processes and consequences, and then re-planning. In addition, according to Kemmis and McTaggart (1988), as cited in in Burns (2010, p. 7), the first cycle of action research may become a continuing, or iterative, spiral of cycles which recur until the action researcher has achieved a satisfactory outcome and feel it is time to stop.

\section{Respondents}

The subject of this research is tenth grade and eleventh grade of all majors. The researcher took a class of English club as the subject of the research which consisted of 20 students; 12 students of tenth grade and 8 students of eleventh grade. There were 6 male students and 14 female students in English club class. The researcher took English club as the subject of the research because English Club' members had willingness to learn and improve their English skills.

\section{Procedure}

This research used Classroom Action Research. McNiff and Whitehead (2006, p. 7) stated that Action research is a form of enquiry that enables practitioners everywhere to investigate and evaluate their work. Action research can be a powerful and liberating form of professional enquiry because it means that practitioners themselves investigate their own practice as they find ways of living more fully in the direction of their educational values. According to Kemmis and Mc'Taggart (2004, p. 18), in general, action research cycle contains planning of change, acting and observing the process and consequences of the change, reflecting on these processes and consequences, and then re-planning.

\section{Planning}

In this phase, researcher identified a problem or issue and developed a plan of action in order to bring about improvements in a specific area of the research context. This was a forwardlooking phase where researcher considered: i) what kind of investigation was possible within the realities and constraints of researcher's teaching situation; and ii) what potential improvements researcher think were possible.

\section{Acting}

The plan is a carefully considered one which involved some deliberate interventions into researcher's teaching situation that researcher put into action over an agreed period of time. The 
interventions are 'critically informed' as researcher question researcher's assumptions about the current situation and planed new and alternative ways of doing things.

\section{Observing}

This phase involved researcher in observing systematically the effects of the action and documenting the context, actions and opinions of those involved. It was a data collection phase where researcher used 'open-eyed' and 'open-minded' tools to collect information about what is happening.

\section{Reflecting}

At this point, researcher evaluated and described the strengths and weaknesses of the teaching learning process. The result of the analysis was consulted with the criteria of success. Meanwhile, the weaknesses in the first cycle were improved to the next cycle. This cycle stopped when the students' score reached the criterion of success, up to 70 in average.

\section{Collecting the Data}

In this research, the researcher used some techniques to collect the data, such as observation, interview, video recording, photograph, and test (pretest and posttest). The data consists of qualitative and quantitative data. According to Hair et al. (1995), as cited in Marczyk (2005, p. 112), qualitative data (also referred to as nonmetric data) are typically attributes, characteristics, or categories that describe an individual and cannot be quantified. Meanwhile, quantitative data (also referred to as metric data) exists in differing amounts or degrees, and they reflect relative quantity or distance. Quantitative data allowed researchers to examine amounts and magnitudes, while qualitative data is used predominantly as a method of describing and categorizing. The quantitative data were obtained from pretest and posttest. The data were collected by using observation of activity in the class, students' interview, audio and video recording, photograph and test. Meanwhile the instrument of this research were lesson plan, observation sheet, form of interview, field note and the result of video recording especially in video dubbing.

\section{Analyzing the Data}

After colleting the data, the next step of the research are analyzing the data. The data were analyzed by using qualitative and quantitative data analysis. In qualitative data analysis, researcher analyzed the data of teaching process through interview, observation, field note, photograph, video and audio recording. According to Mc. Kernan (as cited in Burns 1999: p. 156-160). There 
are five steps in analyzing data, they are assembling the data, coding the data, comparing the data, building interpretation, and report the outcomes. Meanwhile, in quantitative data analysis, there are test before cycle and test after cycle. The researcher found the comparison of students' speaking skill before and after the research from the test. Meanwhile, the researcher needed to compare the mean of test to know there is an improvement or not in students' speaking skill. The formula to determine the mean of pre-test and post-test are as follow:

$$
\begin{aligned}
\bar{X}=\frac{\sum X}{N} \quad \bar{X} & =\text { Mean Score } \\
\Sigma \mathrm{X} & =\text { Total Score } \\
\mathrm{N} & =\text { Total Student }
\end{aligned}
$$

\section{FINDINGS AND DISCUSSION}

The research findings were gathered from several sources of data, including test, observation, and interview. The findings were related to what extent video dubbing can improve students' speaking pronunciation and also the difficulties of applying video dubbing in improving students' speaking pronunciation. In the preliminary study, I found that students' speaking skill were low. Due to pre test in the preliminary study, I found that students' speaking pronunciation were the lowest among other aspects of speaking skill. Therefore, I tried to improve students' speaking pronunciation by using video dubbing.

The result of the research showed the improvement of all aspects of pronunciation; vowels, diphthongs and pronunciation. The overall result of pre test, test after cycle 1 and test after cycle 2 can be seen in Figure 1. 


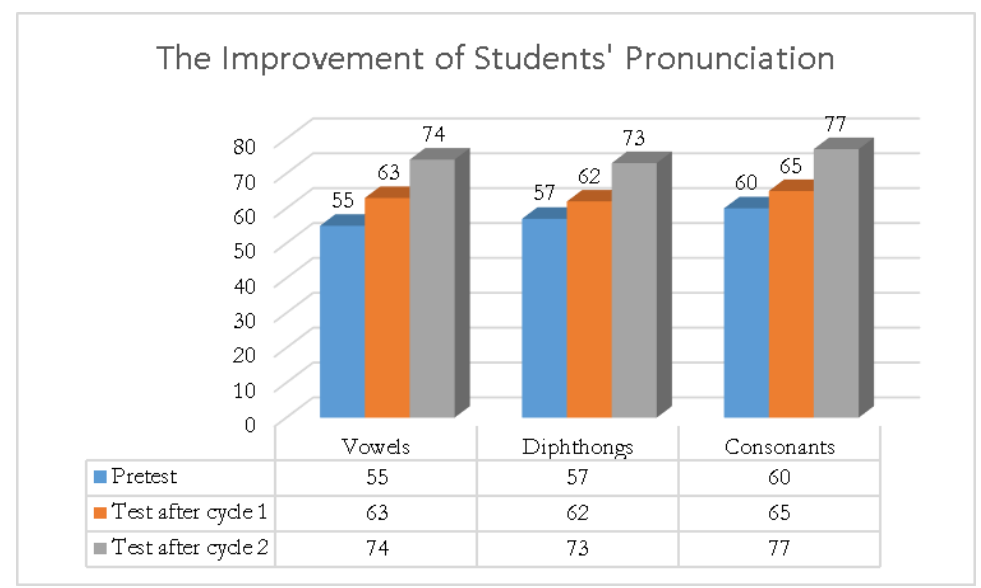

Figure 1. The improvement of Students' Pronunciation from Pretest, Posttest 1, and Posttest 2

Based on the table above, there were improvement of mean score from pre test, test after cycle 1 and test after cycle 2. In the test after cycle 2, each aspect of pronunciation reached minimum score of criterions of success (70), where the mean score of vowels was 74 , diphthongs was 73 and consonants was 77 . Therefore, the researcher stopped to continue the cycle.

Based on the result of students' mean score above, the researcher found that video dubbing can improve students' speaking pronunciation. It was relevant with the statement of Burston (2005, p. 90) who said that video dubbing can provide a rich source of activities in all language skill areas: listening, reading, writing, and speaking. It can also foster advanced grammar, vocabulary acquisition and pronunciation well. From the result of research, video dubbing improved all aspects of speaking pronunciation; vowels, diphthongs, and consonants. The result was relevant with the statement of Zanon (2006), as cited in Florente (2016, p. 63) who said that learning pronunciation by listening to the speech of native speakers, reading movie subtitle, revoicing video, can be beneficial in spoken language activities and help learners improve their language comprehension. Meanwhile, Requena (2016, p. 19) explains that a repetitive element of dubbing activity gives improvement in fluency and also has impact on pronunciation.

\section{E. CONCLUSION}

This research tries to find out how the implementation of video dubbing in teaching speaking. Based on the data analysis, research findings, and discussions in implementing video dubbing to improve the students' speaking pronunciation, it can be concluded that this research is successful because the students' speaking pronunciation improves by implementing video 


\section{Firdaus, How Video Dubbing can...}

dubbing. It is proven by the improvement of the students mean score of speaking test. The improvement contains all aspects of speaking which are vowels, diphthongs, and consonants. Meanwhile, video dubbing can increase the students' behavior in teaching learning process. The students were more enthusiastic and interested in teaching learning process. They did the tasks seriously when they did practice by adjusting their voice with the actor in the video. The repetition of recording process in video dubbing decreased from cycle 1 to cycle 2 . It means that students' confidence increased when they did video dubbing practice.

Hopefully, this research can give awareness about the importance of English learning and facilitate students to improve their speaking, especially in pronunciation. This research can be a guidance for teachers who want to improve students' speaking especially in pronunciation by using video dubbing. In addition, other researchers can use this research as a reference to conduct further research in the same field.

\section{REFERENCES}

Borell, Jonas. (2000). Subtitling or Dubbing. Lund University

Brown, H Douglas. (2004). Language Assessment: Principles and Classroom Practices.USA: Pearson Education.

Burges, Sally., Head, Katie. (2005). How to Teach for Exams. Essex: Pearson.

Burston, Jack. (2005). Video dubbing projects in the foreign language curriculum. Calico Journal, 23 (1), 79-92

Danan, Martine. (2010). Can film dubbing projects facilitate EFL learner's acquisition of English pronunciation?. British Journal of Educational Technology 43(1).

Deterding, D., Poedjosoedarmo, G. (1998). The Sounds of English: Phonetics and Phonology for English Teachers in Southeast Asia. Singapore: Prentice Hall.

Florente, Irene L. (2016). How Movie Dubbing Can Help Native Chinese: Hamline University

Fraser, H. (2001). Teaching Pronunciation: A handbook for Teachers and Trainers. Canberra: Department of Education Training and Youth Affairs

Gilakjani, Abbas Pourhosein. (2016). English pronunciation instruction: A literature review. International Journal of Research in English Education, 1 (1), 1-6

Hughes, Artur. (2003). Testing for Language Teachers. Cambridge: Cambridge University

Kay Hayriye, (2006), Teaching Speaking: Activities to Promote Speaking in a Second Language. The Internet TESL Journal 2(11) 
Volume 5, Number 01, June 2019

Karimzadeh, Pooneh., Ghahroudi, Maryam Rezaei. (2017). English animation dubbing based technique and Iranian intermediate EFL learners' nativelike pronunciation development. International Journal of English Language Education, 5 (2), 1-12

Kemmis, S., McTaggart, R. (2004). The Action Research Planner (Second Edition). Karachi: Aga Khan University, Institute for Educational Development.

Kenworthy, Joanne. (1987). Teaching English Pronunciation. London: Longman

Kreidler, Charles W. (2004). The Pronunciation of English, Second Edition. New Jersey: Blackwell Publishing

Leong, Lai-Mei and Ahmadi, Seyede M. (2017). An analysis of factors influencing learners' English speaking skill. International Journal of Research in English Education, 34-41.

Mahu, Diana-Petruta. (2012). Why is Learning English so beneficial nowadays? Journal of Perspectives on Communication, 2 (4), 374-376

Marczyk G., DeMatteo D., Festinger D. (2005). Essentials of Research Design and Methodology. New Jersey: John Wiley \& Sons, Inc.

Matamala, Anna. (2010). Translations for dubbing as dynamic texts: Strategies in film synchronization. Babel Journal, 56(2), 101-118.

Nunan, David. (2005). Practical English Language Teaching: Young Learners. New York: McGraw Hill.

Nunan, David. (2003). Practical English Language Teaching. New York: McGraw Hill.

Pearson. (2012). Score Guide. London: Pearson PTE Academic

Requena, Alicia Sanchez. (2016). Audio visual translation in teaching foreign languages: contribution of dubbing to develop fluency and pronunciation in spontaneous conversations. Porta Linguarum Journal.9-21.

Richards, Jack C. (2008). Teaching Listening and Speaking: From Theory to Practice. New York: Cambridge University Press

Syakur. (1987). Language Testing and Evaluation. Surakarta: Sebelas Maret University Press

Tănase, Violeta., Cuza, Alexandru Ioan. (2014). Pros and cons of subtitling and dubbing of audiovisual texts in children's programmes and cartoons. Language and Discourse 3, 968-975

Thornbury, S. (2005). How to Teach Speaking. Essex: Pearson

Whitehad, J., McNiff, J. (2006). All You Need to Know about Action Research. London: Sage Publications 